\title{
The Determinants of Elderly Migration in France
}

\author{
Alexandra SCHAFFAR, LEAD, University of Toulon. \\ E-mail: schaffar@univ-tln.fr \\ Michel DIMOU, LEAD, University of Toulon. \\ E-mail: dimou@univ-tln.fr \\ El Mouhoub MOUHOUD, LEDa, DIAL, University of Paris Dauphine \\ E-mail: em.mouhoud@dauphine.fr
}

\begin{abstract}
The aim of this paper is to study the elderly migration in France. First, it tests whether the migration decision relies upon individual characteristics. Second, it examines the spatial trends of this migration and the way the economic, social and environmental characteristics of the French territories determine the retirees' choices of localization. The paper builds upon a unique database of 12.67 million French inhabitants, with information about their personal attributes and locational choices from 2003 to 2008. It also uses an original database with locational characteristics for the French territories at the 364 zones d'emploi level, enabled by the authors. This is the only study on regional migration in France building upon such a thin spatial level of analysis. The paper shows the existence of a spatial path-dependent process in the retirees' migration with the progressive appearance of some top elderly dominated territories, characterized by new opportunities for Silver Economy growth but also high risks of intergenerational conflicts. It also focuses on short distance migration, which is often neglected in the regional migration literature. It shows that the retirees' short-distance migration features different trends than the long-distance migration.
\end{abstract}

Keywords: elderly, retirees, migration, territories, France. 


\section{Introduction}

Elderly migration has considerably developed over the last thirty years. In most countries, the elderly are escaping large metropolitan areas in order to congregate to rural counties with special climatic and natural amenities, while often there is an opposite net flow for younger adults who seem to flock into metropolitan conurbations.

In the United States (US), many retirees quit metropolitan areas in the North and in the Midwest to relocate to the "Sunbelt States" (Hazelrigg and Hardy, 1995; Clark and al, 1996; Hogan and Steinnes, 1996; Newbold, 1996; Glaeser and Tobio, 2008; Jurjevich and Plane, 2009). The demographical growth of some States such as Florida or Arizona strongly depends upon the migration of the elderly: the percentage of immigrants over 60 years old in these two States accounts for almost 30\% of each year's arrivals (US Census, 2011). Similar trends can be observed in Great Britain, Sweden and Germany, where the retirees' migration is important. Elderly households often quit large urban centers, such as London, Berlin or inland Swedish cities in order to relocate to southern, less urbanized and mild-climate areas such as Brighton, the Baden-Württemberg region or the Baltic Sea recreational areas and even to southern France (Ermisch and Jenkins, 1999; Tatsiramos, 2006; Oliver, 2008; O'Reilly and Benson, 2009; Niedomysl and Amcoff, 2011; Lundholm, 2015). In France, the non-working migrants represent 40.5\% of total regional migration flows (INSEE, 2008). Among them, 25\% are retirees. Some studies have shown that the seniors' migration in France is not a recent phenomenon. During the 1990s, one third of the elderly were moving immediately after retiring: almost half of these migrations (44\%) represented long-distance moves, with people moving out of the region where they had been working until retirement (Christel, 2006).

The impacts of these migrations on real estate prices, economic activities and local public goods' provision are important both for the regions of departure and for the regions of arrival of the migrants. They often lead to the development of specific localized markets, known as Silver Economies ${ }^{1}$, which represent a set of local economic activities that aim to respond to the final demand from elderly households. Nevertheless, sometimes, the top retirement destinations may also experience problems in managing dramatic demographic, economic and cultural changes over a relatively short period of time (Rice and Pepper, 1997; Walters, 2002).

The aim of this paper is to study the dynamics of elderly migration in France by focusing on two different issues. First, it examines whether the migration decision relies upon personal attributes, by using an original dataset of 12.67 million French inhabitants of more than 18 years old, provided by the French Institute of Statistics (INSEE), with information about age, gender, educational skills, family situation, professional situation, geographical origins and migration behavior between 2003 and

\footnotetext{
${ }^{1}$ The term of Sllver Economy has been introduced in Germany, at the end of the nineties, in order to describe the economic development of some regions which concentrated an important number of elderly households.
} 
2008. Second, it focuses on the spatial trends of the elderly migration and on the way the economic, social and environmental characteristics of the French territories determine ingoing and/or outgoing elderly flows. Our data concerns migration flows within and between the French "zones d'emploi", which represent a quite significant spatial level of analysis from an economic point of view, contrary to the larger institutionally defined spatial levels (Department or Region) used in previous studies ${ }^{2}$. As far as we know, there is no other study on regional migration in France using such a thin level of spatial analysis and such a large database.

The database on the locational characteristics of the zones d'emploi has been built by the authors. It contains original information about the economic development, the industrial specialization and the labor market conditions of each zone. It also features socioeconomic characteristics for each zone such as demographics, median imposable income level, income disparities (estimated by the index of Gini) and criminality rate. Finally, it gives information about the environmental characteristics of each zone, mainly concerning its climate.

This paper delivers three series of results. First, when studying the way personal attributes affect the migration decision, it clearly shows that the wealthier and higheducated people who used to live, before retirement, in large agglomerations with high rates of economic activity are far more mobile after retiring than the low-educated ones. Nevertheless, this is less accurate for intra-zone movements, which feature an important low income and low human capital migration flow. The paper shows that the territories which meet the highest rate of intra-zone migration are different than the ones characterized by intensive inter-zone migration. This is an innovative issue, discussed in this paper, since short-distance migration has often been neglected in most regional migration theories.

Second, the location preferences of the elderly migrants mainly concern smalltown areas that feature a high degree of cultural and environmental amenities and low crime rates. The elderly migration seems to be a path-dependent process, with newly retiring households often migrating towards the areas where previous retirees have chosen to locate. The paper shows the progressive appearance of a new type of area the elderly migrants' dominated one, which is likely to cover a large part of the French territory during the $21^{\text {st }}$ century, when considering the progressive changes in the French pyramid of ages.

Third, the distance of elderly migration is positively correlated with some of the zones d'emplois locational characteristics, but not all. Retirees are eager to relocate to a longer distance only in order to reach the sunniest and more environmentally and

\footnotetext{
${ }^{2}$ A French «zone d'emploi » is mainly determined by the workers' commuting trips, while also taking into account some productive specialization criteria. It represents a performing spatial level for studying regional dynamics in France. There are 364 zones d'emploi in metropolitan France, compared to the 96 Departments and the 13 Regions.
} 
socially attractive areas. Heliotropism remains the basic engine of the French retirees' long-distance migration.

The paper is organized as follows: Section 2 examines the theoretical background on elderly migration. Section 3 gives information on data issues and provides summary statistics on the French retirees' migration. Section 4 delivers results from several Probit models which test the way individual characteristics and territorial patterns influence the decision to migrate and runs a Heckman model to test how these characteristics affect the distance of migration. The concluding section summarizes and discusses these results and the way they may influence future French regional policies and planning.

\section{Theoretical background}

The economic literature on later-life migration has developed since the 1980s. Until then, regional economics seemed to follow Becker's (1964) assumption that age is negatively correlated with migration because of the decrease in expected lifestyle gains from a new location. Gallaway (1969) considers that, contrary to young workers, retirees seem less eager to move away from the city and the region where they have been working previously because of the strong social ties they developed in their local environment during their working years. When migrating, this social capital, which also may generate some private benefits, is lost (Di Pasquale and Glaeser, 1999).

While most migration and regional growth models assume that regional mobility only concerns young households, early empirical work from Wiseman and Roseman (1979), Graves and Linneman (1979), Rudjitis (1984) or Feinstein and McFadden (1989) have shown that elderly migration steadily increases after 1970, when the afterwar baby-boomer generation progressively started attaining retirement (Plane and Rogerson, 1991). Elderly migration theory has developed by focusing on three major themes: the decision-making process, the geographical patterns of migration and the impact of migration on origin and destination communities (Liaw and Ledent, 1988; Fokkema, 1996; Longino, 2001; Walters, 2002).

By arguing that the elderly migration patterns cannot be explained within a generalized mobility framework that emphasizes employment motivation, family life cycle and life-style motivations, Wiseman and Roseman (1979) develop an early model on the elderly migration from a decision-making perspective in order to understand who is migrating and why. They build a typology of elderly migrants defined in terms of the circumstances, the decision processes and the expected geographical outcomes of an eventual residential relocation.

Graves and Knapp (1988) consider that the mobility patterns of the elderly can be studied as a subcase of a more generalized life-cycle migration model which interacts individual-specific traits - for example, age, income, human capital level, family situation - and location-specific characteristics, such as cultural amenities, climate, the quality of 
the natural and social environment, the provision of local public goods and the local taxation system. The elderly are characterized by spatially invariant incomes, such as pensions or dividends, which means that their mobility decision and localization choice mainly depends upon amenities and lifestyle differentials, but also upon local and regional rents and tax policies' issues. Gobillon and Wolff (2011) revisit this assumption, by arguing that in France and in the rest of Europe retirement usually goes along with a lower income (pension) compared to the end-of-the-working-life wage, which drives many retiring households to compensate their higher demand for leisure with lower rents and housing costs.

When taking into account working people's mobility and amenity capitalization in both real estate and labor markets, Graves and Knapp (1988) show that retired workers clearly prefer locations where the value of amenities is capitalized in labor markets rather than in land markets. Conway and Houtenville (1998) and Gale and Health (2000) find similar results and show that seniors "vote with their feet" and prefer destinations with low property taxes and declining sales taxes, where the burden of publicly provided goods is more than proportionately borne by wage earners. Assadian (1995) argues that migrants of all ages prefer destinations with low public taxes, but, unlike others, seniors are more eager to locate to areas with low public expenditures.

In the US, empirical observation seems to confirm the assumption that the elderly migrate towards some Sunbelt States' rural or middle-size cities areas instead of localizing to larger agglomerations (Longino, 1998; Gale and Heath, 2000). When investigating the determinants of the US elderly interstate migration from 1985 to 1990, Newbold (1996) delivers evidence that local natural amenities are more important than medical expenditures and cultural amenities. Walters (1994) and Waltert and Schläpfer (2010) stress the fact that mild winters and clear summers are quite attractive for retirees. However, although there are different climate-determinant components, only dry summers and sunshine seem to be significant for elderly migration. According to Rappaport (2007), the steady rising of per capita income, higher longevity and increasing early-retirement decisions lead to the appearance of an important middleclass of relatively wealthy and still mobile retirees willing to reconsider their localization and lifestyle choices. Using a 1970-2000 database on US households' mobility, Rappaport (2007) gives empirical support for the relation between age, migration and climate. Glaeser and Gottlieb's (2009) findings also confirm the assumption of an elderly migration model where retirees choose sunny, but not urban congested areas: they move to the Sunbelt States but prefer small locations, rather than big cities, where the rent levels remain low.

In France, this model does not work so nicely because housing supply increases much more slowly than in the US, but also because retirement may go along with a lower income level. Using data from both the 1992 Trois Generations survey and the 19942001 French Europanel Survey, Gobillon and Woff (2011) deliver interesting results on the motives of migration and on the housing adjustments made by the retirees when 
relocating. They show the importance of family ties and the "being a grand-parent" status in the elderly migration decision. Cavailhès and al (2009) regress real estate prices to territorial quality-of-life proxies that are strongly influenced by climate and average annual temperature. When comparing the French regions, Joly and al. (2010) show that a higher mean temperature of $1^{\circ} \mathrm{C}$ between April and October is consistent with a $5 \%$ increase in real estate prices (except for Paris).

Gobillon and Le Blanc (2004) and Flavin and Nakagawa (2008) consider alternative models where housing adjustment, amenities and migration costs interact in the migration decision of the elderly. Christel (2006) and Gobillon and Laferrere (2006) deliver important empirical work showing that in France, elderly migration goes along with a net decrease in the dwelling size. Angelini and Laferrere (2012) apply this analysis in different European countries and produce similar findings.

When reviewing the broader implications of elderly mobility, it is obvious that these flows have important implications for both the regions of departure and arrival. Newbold (2008) argues that this migration has a positive economic impact for the destination areas and plays an important role in redistributing income across Canadian provinces. Elderly migration affects the composition of publicly provided goods in the long run (fewer schools, kindergartens or sports fields, but more hospitals or cultural amenities). Poterba (1998), Ladd and Murray (2001) and Grandstein and Kaganovich (2004) raise the assumption of an intergenerational conflict in local education financing. Holtz-Eakin and al (2003) find dramatic age heterogeneity in preferences for education spending among migrants. Conway and Rork (2006) use an important US county-level database to investigate intergenerational conflicts and, contrary to previous models, show that elderly migration is more likely to cause changes in a State's taxes and equipment policies, rather than be influenced by them.

Finally, elderly migration changes the levels of rents and real estate prices. Elderly migration does not affect wages but disturbs the rent levels and the local real estate market, where all households, retired or not, compete. Chiuri and Jappelli (2010) introduce the assumption that elderly households' arrivals may lead, in some areas, to an opposite movement for young households unable to handle the pressure and the rising prices in the real estate market. Some regions may find themselves locked in a long-term demographical path characterized by the growing importance of elderly and retired households, with important implications for the regional economic activity.

\section{Data and descriptive analysis}

The specific database from the French Institute of Statistics (INSEE) used here provides information about the location of 12.667 million people over 18 years old, in 2003 and 2008. This database represents almost one third of the total French population. Information is available at the 364 zones d'emploi level, and also at the 36,570 French communes' (counties) level. This means that we can track important long 
or short migration movements both between and within the zones d'emploi. The only flows we are not able to measure are those regarding individuals that have moved within their own county - but this can hardly be considered as a migration movement. Calculations are based on INSEE's provided person weights per zone.

Table 1: Individual characteristics variables

Total
population

\begin{tabular}{|c|c|c|c|c|c|}
\hline Variable & Type & Proportion & Observ & Proportion & Observ \\
\hline \multirow[t]{2}{*}{ MIGCOM } & 0 & 0.6990 & 8858215 & 0.8606 & 3511635 \\
\hline & 1 & 0.3010 & 3813653 & 0.1394 & 568965 \\
\hline \multirow[t]{2}{*}{ MIGZE } & 0 & 0.8727 & 11058673 & 0.9523 & 3886062 \\
\hline & 1 & 0.1273 & 1613195 & 0.0477 & 194538 \\
\hline \multirow[t]{2}{*}{ EDUC } & Less_HS & 0.5768 & 7309185 & 0.7801 & 3183448 \\
\hline & More_HS & 0.4232 & 5362683 & 0.2199 & 897152 \\
\hline \multirow[t]{5}{*}{ FAM } & Alone & 0.2283 & 2892605 & 0.3033 & 1237452 \\
\hline & Couple & 0.3391 & 4297465 & 0.6967 & 2843148 \\
\hline & Monop & 0.0579 & 733830 & & \\
\hline & Smal_Fam & 0.2974 & 3724451 & & \\
\hline & Large_Fam & 0.0773 & 979219 & & \\
\hline \multirow[t]{8}{*}{ SPS } & Farmer & 0.0121 & 0.0121 & & \\
\hline & Individ.Entrep & 0.0501 & 0.0044 & & \\
\hline & White Collar & 0.1273 & 0.0062 & & \\
\hline & Prof_inter & 0.1530 & 0.0071 & & \\
\hline & Employee & 0.1079 & 0.0060 & & \\
\hline & Blue Collar & 0.1867 & 2366169 & & \\
\hline & Retiree & 0.3111 & 3942289 & & \\
\hline & Non_Working & 0.0518 & 656089 & & \\
\hline \multirow[t]{2}{*}{ OWN } & 0 & 0.3888 & 4926281 & 0.2392 & 975971 \\
\hline & 1 & 0.6112 & 7745587 & 0.7608 & 3104629 \\
\hline \multicolumn{2}{|l|}{ Variable } & Mean & Std Dev & Mean & Std Dev \\
\hline \multicolumn{2}{|l|}{$\mathrm{AGE}$} & 49.09 & 17.39 & 68.38 & 9.85 \\
\hline \multicolumn{2}{|c|}{ r of obs for total population: } & \multicolumn{2}{|c|}{12671868} & & \\
\hline \multicolumn{2}{|c|}{ of obs for retirees/elderly: } & \multicolumn{2}{|c|}{4080600} & & \\
\hline \multicolumn{2}{|c|}{ of weigthed obs for working } & 1: 7591 & & & \\
\hline
\end{tabular}

Data: INSEE; estimations: authors

In $2008,30.10 \%$ of the persons included in our dataset had moved out of the county they used to live in 2003, which corresponds to a rather high degree of mobility in Europe. More than one third (12.73\%) also moved out of their 2003 zone d'emploi. Among these migrants, only $12.05 \%$ are retirees, which means that the elderly are less mobile than younger people. Table 1 lists the proportion of the French inhabitants migrating out of their county or their zone d'emploi. The key variable MIGCOM and 
MIGZE are binary variables that feature a person's migration decision at the county and the zone d'emploi level between 2003 and 2008 (1 if the person has moved out of his/her 2003 residential area, 0 otherwise). Among the retirees, 13.9\% have moved out of their counties. One third of these migrations have also led to a change in the zone d'emploi.

Table 1 lists the personal attributes variables used in this study such as the age of the person, his/her educational level, his/her professional status, the type of household and the real estate situation, that is, the fact that a person is an owner or a renter of his/her dwelling. It provides some descriptive statistics both for the total population and for the retirees.

AGE is defined by a person's age in years. The mean age for the total population of our database is 39.29 years old, very close to the national mean age in France, which was of 39.7 years old in 2008. The mean age for people over 18 is 49.09 , while the mean age for the retirees is 68.38 years old. We also calculate the AGE-squared variable in order to model more accurately the effect of age, which may have a non-linear relationship with the migration decision.

EDUC measures each person's level of educational capital. We consider two levels of educational attainment, which give, de facto, a proxy for each person's number of years of education: either less than the high school degree (baccalaureate) or with/more than the high school degree which also features all the different levels of the University degrees. One should note that $42.32 \%$ of the French population enters the last category (INSEE, 2015). Among the elderly, only $21.99 \%$ have at least a high school level degree while the rest, $78.01 \%$, have quit the French educational system before the end of the high school. These features clearly show the changes in access to higher education in France: in 1970, only 20\% of the 18 year old French people achieved the 7 years of secondary school's studies leading to the baccalaureate; in 2010, this proportion increased up to 70\% (MENESR, 2014).

FAM is the household type. We admit five different categories of households: (1) living alone, (2) living as a couple, (3) forming a mono-parental family, (4) forming a nuclear family, or (5) living within a large family. Situations 1 and 3 may be considered as the most vulnerable from a social point of view; these two types of households represent together $28.6 \%$ of our database and, more generally, of the French population. For retirees, we only consider two options, being alone $(30.33 \%)$ or otherwise $(69.67 \%)$ which basically corresponds to the second category (living as a couple).

SPS defines a person's socio-professional status. The French National Statistical Institute defines 8 different types of status: (1) farmers, (2) individual entrepreneurs, which includes all individual type activities from merchants to artisans, (3) white collar workers, (4) blue collar workers, (5) employees, (6) intermediate professions, such as teachers, social workers or health services workers, (7) retirees and finally (8) the other 
non-working population. Unemployed people and job seekers do not appear separately but are classified according to their last professional experience. Retirees represent $31.11 \%$ of the dataset.

Finally, OWN indicates whether a person is an owner of his/her house/apartment or a tenant (renter). As predicted, there is a higher proportion of retirees $(76.08 \%)$ who are real estate owners than the rest of the population $(61.12 \%)$.

Table 2 features some basic statistics intra-zone and inter-zone migration with regards to personal attributes.

Table 2: Personal attributes and intra-zone and inter-zone migration

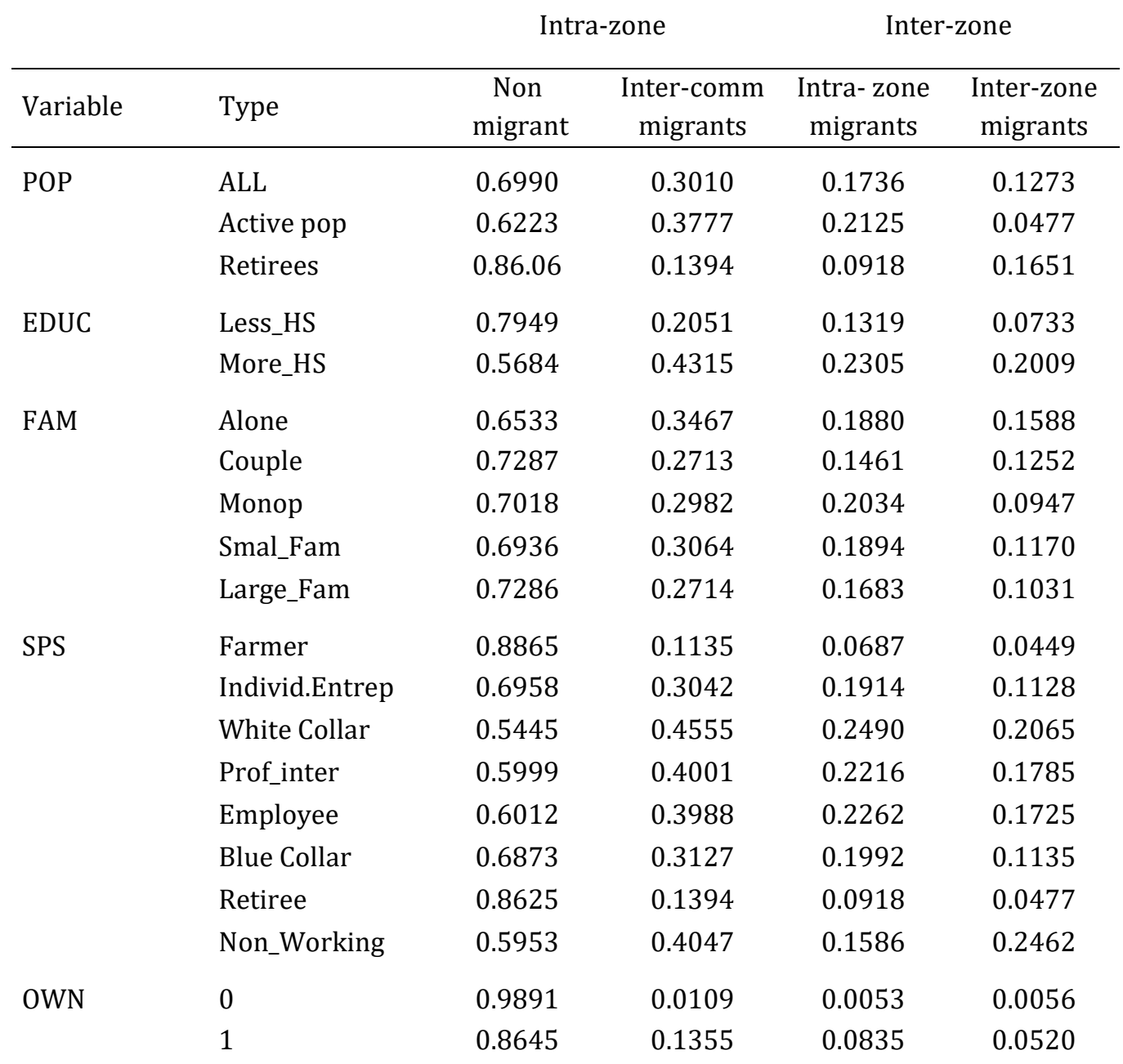

Data: INSEE; calculations: authors

Table 2 clearly shows that personal attributes influence the migration decision and the migration destination. People with a lower educational level, mono-parental families, farmers, small entrepreneurs and blue-collar workers move eagerly within a zone's limits but seem reluctant in quitting their initial zone d'emploi. On the contrary, people with high human capital, white collar jobs and low local family ties (living alone or in couple) are likely to move to a longer distance out of their initial zone d'emploi. 
Retirees and non-working people seem less eager to migrate than working people and when they decide to do it, they choose a rather close destination. Table 3 gives information about the migration distances.

Table 3: Migration distance (from departure to arrival zone)

\begin{tabular}{l|cccc} 
Distance & Mean & Std. Dev. & Min & Max \\
\hline Total & 229.93 & 211.33 & 10 & 1006 \\
Working pop & 246.46 & 231.49 & 10 & 1006 \\
Retirees & 204.58 & 200.21 & 16 & 971 \\
& & & Data: INSEE; calculations: authors
\end{tabular}

Regarding the spatial distribution of the elderly migrants, the attractiveness of the southern and western French zones, contrasts with a series of negative rates that feature the northern and north-eastern French zones d'emploi. Map 1 delivers information about the net total migration for each zone - that is, incoming minus outgoing people reported to the total zone d'emploi's population - for metropolitan France from 2003 to 2008, while Map 2 focuses specifically on elderly migration. Both maps seem to confirm a general behavioral trend of people leaving the northern and eastern cold and industrial areas to go towards the French Sunbelt, that is, the Mediterranean French Riviera and the South-West Atlantic Ocean recreational areas.

Map 1: Net migration rates in the French zones d'emploi 2003-2008

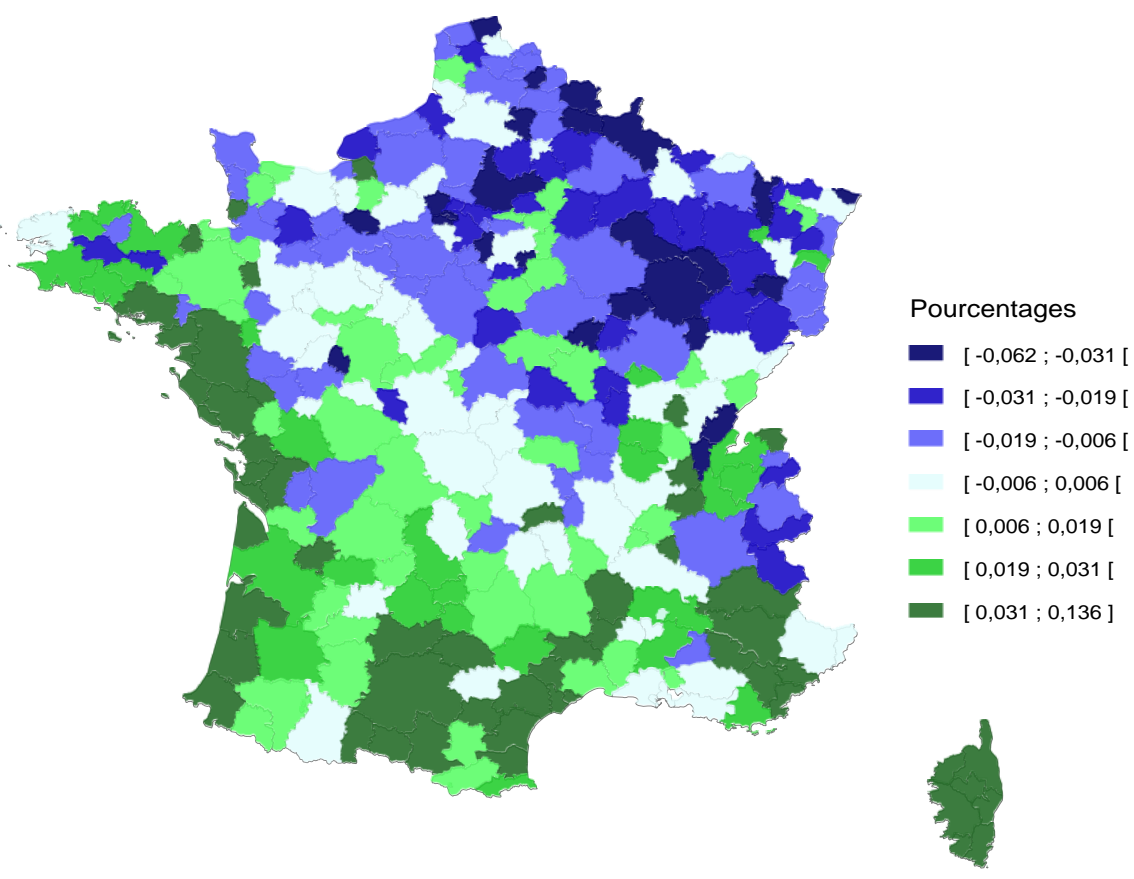

jée avec Cartes \& Données - ๑ Articque

Nevertheless, for elderly, there are also several zones with positive migration rates in the Northern and Eastern regions, usually out of the large metropolitan areas. They represent the best choice for a series of retired migrants who do not wish, or 
simply cannot, move further away but still decide to leave their initial zone d'emploi. For example, this is the case for the zones of Berck, Chateau-Thierry or Montbard in the northern part of France, next to Lille. The South Bretagne peninsula and some areas in the Central Region between Poitiers and Blois, also feature positive rates of elderly migration. Paris and its surrounding areas and the northern industrial belt feature negative rates for net elderly migration between 2003 and 2008. Finally, it is important to note that $24.72 \%$ of elderly migrants represent people who return to their particular homeland and birthplace after retirement, which is independent from distance.

Map 2: Net elderly migration rates in the French zones d'emploi 2003-2008

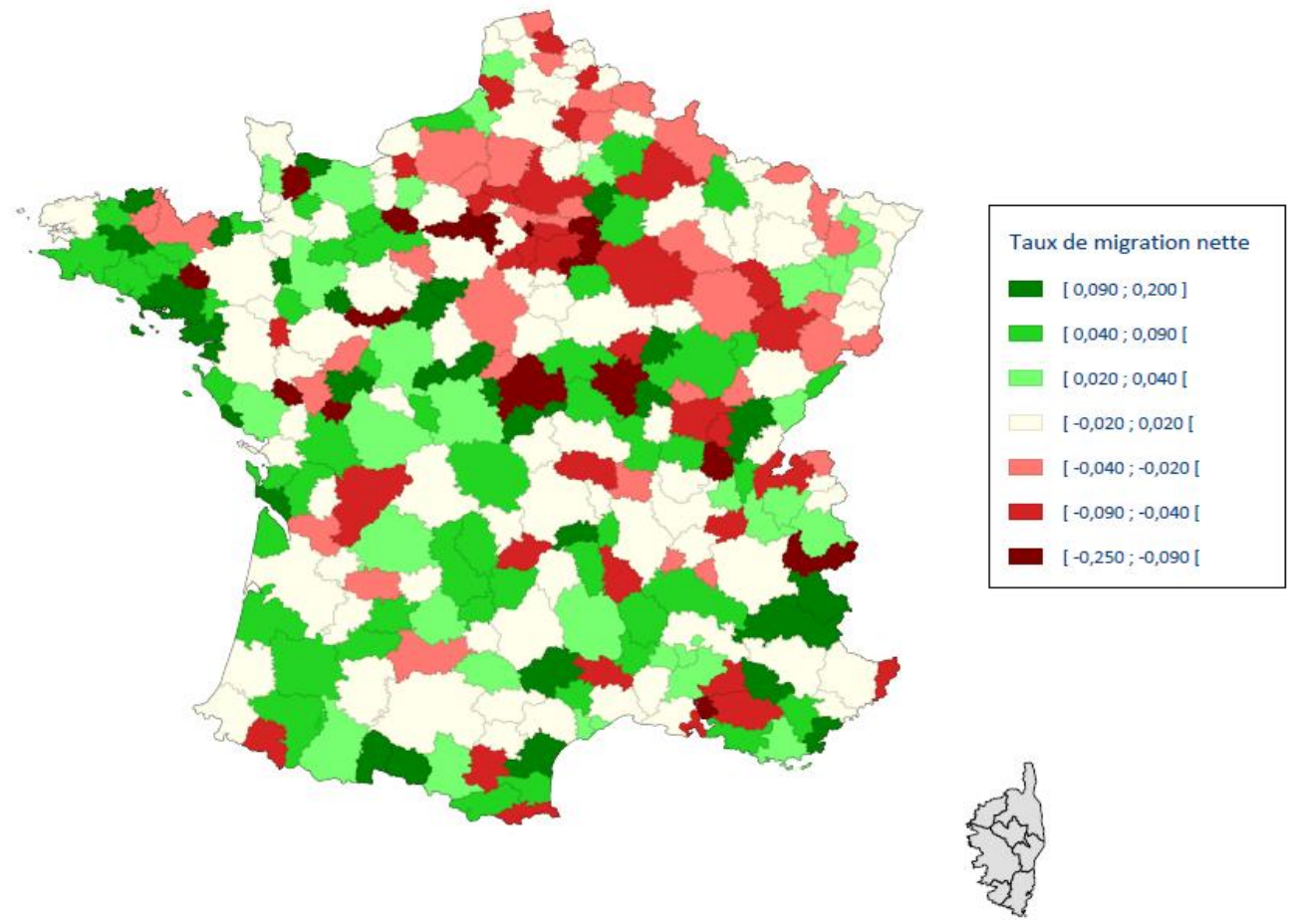

Table 4 provides a list of the locational characteristics for the 364 French zones d'emploi and summary statistics.

SUN is a climate-variable indicating the mean yearly number of hours of sunshine in every zone. Data is provided by the official French Weather Forecast Agency (France Meteo). One can notice the difference between the sunniest French zones d'emploi (between Saint-Tropez and Hyeres), located in the Mediterranean Department of Var in the French Riviera, which features 2801 hours of sunshine per year, and northern France's Ardennes zone with almost 50\% of less sunshine (1440 hours).

ELD STOCK is a variable that represents the proportion of elderly to the total population of the zone. This variable is meant to capture imitation behaviors and pathdependent migration movements when newly retired people decide to move towards the areas previous retirees have chosen to locate. Rural southern zones are characterized by a strong proportion of elderly compared to the urbanized areas in the northern and central French territories. In order to avoid endogeneity issues, we use an 
instrumental variable (REPATR) that aims to capture the effects of the exogenous shock that occurred in France in the early 1960s, with the repatriation of almost one million French citizens living in Algeria (mostly known as "pieds-noirs"), after this country's independence. The French Statistical Institute (INSEE) has provided original data for 780,000 French citizens who have migrated from Algeria to the French mainland between 1962 and 1968: a quarter (25.5\%) of these migrants have moved within the four South-Eastern Mediterranean French Departments (Bouches du Rhône, Var, AlpesMaritimes, Herault), which feature climatic conditions and a lifestyle closer to the ones that these migrants have left than the rest of the French territory. This led to an important demographical increase and a generational gap in these areas. In 2008, the zones d'emploi of these four Departments featured a higher proportion of elderly than the other zones.

Table 4: List of locational characteristics variables

\begin{tabular}{l|cccc} 
Variable & Mean & Std. Dev. & Min & Max \\
\hline SUN & 1889.723 & 329.555 & 1440 & 2801 \\
ELD. STOCK & 1.123 & 0.203 & 0.589 & 1.733 \\
CRIM & 48.656 & 15.734 & 19.4 & 98.7 \\
MED FISC.INC & 17949.66 & 1858.085 & 14186 & 28138 \\
GINI & 0.336 & 0.025 & 0.273 & 0.459 \\
SCOL & 1.031 & 0.181 & 0.424 & 1.592 \\
SIMM & 1.088 & 0.982 & 0.314 & 8.311 \\
IINT & 0.642 & 0.245 & 0.239 & 2.014 \\
REPATR & 0.009 & 0,012 & 0.001 & 0.069
\end{tabular}

CRIM is the criminality rate and may indicate local social unrest. MED FISCINC is the median fiscal income in each zone and GINI, the Gini index, measures the disparities level in local incomes. All these variables deliver information about income and social inequalities between and within the French zones d'emploi. However, MED FISCINC may also be considered as a good proxy for real estate prices.

SCOLL indicates the level of provision of public or private collective services in order to test whether the disparities between the French zones may have influenced the retirees in choosing a new life-style destination. Following the decentralization laws of 1982, the level of the collective services mainly depends upon local and regional social policies; it features strong disparities among the French zones. Finally SIMM and IINTI may be considered as two territorial attractiveness variables. SIMM represents the part of a series of services related to tourism, such as the management of national or regional parks or the administration of real estate properties to the zone's GDP. IINTI features a series of specific metropolitan-type functions and jobs that are usually related to high added-value services that are part of the total zone's employment, such as architects, lawyers, managers and marketing councilors. 
Finally, the RETURN variable aims to capture the decision, for some people, to return to their homeland (birthplace) after retirement. This is an important motive for people to move, especially because it usually goes along with lower migration costs.

\section{Empirical models for elderly migration in France}

We first run a series of probit models in order to test the probability for elderly to migrate between 2003 and 2008 between counties, within or between the zones d'emploi, according to their personal attributes. Then, we focus on the way the locational characteristics of the zones affect intra-zone migration rates. Next, we build a probit model considering simultaneously locational characteristics and personal attributes in the elderly's decision to migrate between the zones d'emploi. From a methodological point of view, we follow Beckhusen, Florax, Poot and Waldorf (2013). Finally, we run a two-stage Heckman model to study how the differences in locational characteristics among the French zones d'emploi affect the migration distance, that is, the distance between the departure and the arrival zone.

In all models, locational characteristics are measured by taking into consideration the differences in values between the departure zone and the arrival zone for each migrant, except when considering intra-zone migration. The $\beta$ parameters and robust standard errors in all models are estimated by the Maximum of Likelihood method separately for the working population's and the retirees' samples. All usual statistical tests (Wald test, likelihood ratio test) have been performed.

Table 5 delivers the results from the probit model when examining the way personal attributes affect migration at different spatial levels, both for the working population and for the retirees.

Age negatively affects the probability to migrate. Young people are more likely to migrate than older ones, which is consistent with Becker's (1964) assumption. Younger retirees also are more eager to migrate than older retirees. Age-squared is significant and positively correlated with the probability to migrate for the working population but negatively correlated for the retirees. This can be explained by the fact that some people choose to migrate some years before or just after retirement to the area they wish to live after retiring. For the elderly, the migration decision is usually taken during the first years after retirement; if not, the probability to migrate falls.

Turning next to educational attainment, one can clearly notice that it strongly affects the migration decision. People with lower diplomas and lesser education are less eager to migrate, both for the working population and the retiree samples. The family type affects both the working population's and the retirees' probability to migrate. As expected, with regard to the working population, young, single and without family individuals are more willing to move than the workers who already have founded a family (Courgeau and Meron, 1995). With regard to the retirees, being alone seems to be 
a more favorable condition for migrating than living as a couple. Börsch-Supan et al. (1990) have argued that elderly migration and location is not independent from the children's choices and family arrangements. Bonnet and al. (2010) study the effect of widowhood on location choices with similar results. Several studies suggest that the desire to live next to adult children is an important factor for elderly migration (Silverstein, 1995; Rogerson and al., 1997). However, it remains quite difficult to introduce the spatial convergence of parents' and children's location within a large dataset study.

Table 5: An Empirical Probit for regional migration in France

\begin{tabular}{|c|c|c|c|c|c|c|}
\hline & \multicolumn{3}{|c|}{ Working population } & \multicolumn{3}{|c|}{ Retirees } \\
\hline & Counties & $\begin{array}{c}\text { Within } \\
\text { (Intrazone) }\end{array}$ & $\begin{array}{l}\text { Between } \\
\text { Interzone }\end{array}$ & Counties & $\begin{array}{c}\text { Within } \\
\text { (Intrazone) }\end{array}$ & $\begin{array}{l}\text { Between } \\
\text { Interzone }\end{array}$ \\
\hline Age & $\begin{array}{l}-0.0786^{* * *} \\
(0.000138)\end{array}$ & $\begin{array}{l}-0.0628^{* * *} \\
(0.000176)\end{array}$ & $\begin{array}{l}-0.0314^{* * *} \\
(0.000146)\end{array}$ & $\begin{array}{l}-0.0842^{* * *} \\
(0.000205)\end{array}$ & $\begin{array}{l}-0.0537^{* * *} \\
(0.000162)\end{array}$ & $\begin{array}{r}-0.049514^{* * *} \\
(0.000204)\end{array}$ \\
\hline $\operatorname{Age}^{2}$ & $\begin{array}{l}0.000516^{* * *} \\
(0.0000014)\end{array}$ & $\begin{array}{l}0.000330^{* * *} \\
(0.0000019)\end{array}$ & $\begin{array}{l}0.000217^{\text {*** }} \\
(0.0000015)\end{array}$ & $\begin{array}{r}-0.000321^{\text {*** }} \\
(0.000002)\end{array}$ & $\begin{array}{c}-0.00033^{* * *} \\
(0.000002)\end{array}$ & $\begin{array}{l}-0.00026^{* * *} \\
(0.000001)\end{array}$ \\
\hline $\begin{array}{l}\text { Education } \\
\text { BAC - }\end{array}$ & $\begin{array}{l}-0.232^{* * *} \\
(0.00115)\end{array}$ & $\begin{array}{l}-0.206^{* * *} \\
(0.00140)\end{array}$ & $\begin{array}{l}-0.145^{\text {*** }} \\
(0.00124)\end{array}$ & $\begin{array}{l}-0.456^{* *} \\
(0.00515)\end{array}$ & $\begin{array}{l}-0.366^{*} \\
(0.0940)\end{array}$ & $\begin{array}{l}-0.213^{* *} \\
(0.0471)\end{array}$ \\
\hline $\begin{array}{l}\text { Education } \\
\text { BAC + }\end{array}$ & $\begin{array}{c}0.156^{* * *} \\
(0.00126)\end{array}$ & $\begin{array}{l}0.0918^{* * *} \\
(0.00146)\end{array}$ & $\begin{array}{l}0.101^{* * *} \\
(0.00133)\end{array}$ & $\begin{array}{c}0.211^{* *} \\
(0.00608)\end{array}$ & $\begin{array}{l}0.0662^{*} \\
(0.0909)\end{array}$ & $\begin{array}{l}0.314^{* * *} \\
(0.00597)\end{array}$ \\
\hline Alone & $\begin{array}{l}0.202^{* * *} \\
(0.00122)\end{array}$ & $\begin{array}{l}0.171^{* * *} \\
(0.00148)\end{array}$ & $\begin{array}{l}0.0696^{* * *} \\
(0.00129)\end{array}$ & $\begin{array}{l}0.106^{* * *} \\
(0.00236)\end{array}$ & $\begin{array}{l}0.211^{* * *} \\
(0.00178)\end{array}$ & $\begin{array}{l}0.0342^{* * *} \\
(0.00092)\end{array}$ \\
\hline Couple & $\begin{array}{l}0.181^{* * *} \\
(0.00110)\end{array}$ & $\begin{array}{c}0.220^{* * *} \\
(0.00133)\end{array}$ & $\begin{array}{l}-0.00275^{*} \\
(0.00117)\end{array}$ & & & \\
\hline $\begin{array}{l}\text { Mono } \\
\text { Parental }\end{array}$ & $\begin{array}{l}-0.0160^{* * *} \\
(0.00184)\end{array}$ & $\begin{array}{l}-0.139^{* * *} \\
(0.00241)\end{array}$ & $\begin{array}{l}0.0719^{* * *} \\
(0.00194)\end{array}$ & & & \\
\hline $\begin{array}{l}\text { Large } \\
\text { Family }\end{array}$ & $\begin{array}{l}-0.0863^{* * *} \\
(0.00158)\end{array}$ & $\begin{array}{l}-0.0278^{* * *} \\
(0.00200)\end{array}$ & $\begin{array}{l}-0.0789^{* * *} \\
(0.00171)\end{array}$ & & & \\
\hline Farmer & $\begin{array}{l}-0.686^{* * *} \\
(0.00487)\end{array}$ & $\begin{array}{l}-0.467^{\text {*** }} \\
(0.00644)\end{array}$ & $\begin{array}{l}-0.583^{* * *} \\
(0.00536)\end{array}$ & & & \\
\hline $\begin{array}{l}\text { White } \\
\text { Collar }\end{array}$ & $\begin{array}{c}0.172^{* * *} \\
(0.00207)\end{array}$ & $\begin{array}{c}0.177^{* * *} \\
(0.00255)\end{array}$ & $\begin{array}{l}0.0534^{* * *} \\
(0.00220)\end{array}$ & & & \\
\hline $\begin{array}{l}\text { Profession } \\
\text { Interm }\end{array}$ & $\begin{array}{l}-0.0226^{* * *} \\
(0.00200)\end{array}$ & $\begin{array}{l}0.0121^{* * *} \\
(0.00248)\end{array}$ & $\begin{array}{l}-0.0430^{* * *} \\
(0.00213)\end{array}$ & & & \\
\hline Employee & $\begin{array}{l}-0.0411^{* * *} \\
(0.00212)\end{array}$ & $\begin{array}{l}-0.0123^{* * *} \\
(0.00262)\end{array}$ & $\begin{array}{l}-0.0365^{* * *} \\
(0.00225)\end{array}$ & & & \\
\hline $\begin{array}{l}\text { Blue } \\
\text { Collar }\end{array}$ & $\begin{array}{l}-0.180^{* * *} \\
(0.00198)\end{array}$ & $\begin{array}{l}-0.215^{* * *} \\
(0.00250)\end{array}$ & $\begin{array}{l}-0.0490^{* * *} \\
(0.00210)\end{array}$ & & & \\
\hline Non_Active & $\begin{array}{l}-0.0369^{* * *} \\
(0.00252)\end{array}$ & $\begin{array}{c}0.210^{* * *} \\
(0.00300)\end{array}$ & $\begin{array}{l}-0.310^{* * *} \\
(0.00271)\end{array}$ & & & \\
\hline Owner & $\begin{array}{l}-0.361^{* * *} \\
(0.000898)\end{array}$ & $\begin{array}{l}-0.291^{* * *} \\
(0.00111)\end{array}$ & $\begin{array}{l}-0.224^{* * *} \\
(0.000959)\end{array}$ & $\begin{array}{l}-0.477^{* * *} \\
(0.00101)\end{array}$ & $\begin{array}{l}-0.411^{* * *} \\
(0.00209)\end{array}$ & $\begin{array}{l}-0.635^{* * *} \\
(0.00108)\end{array}$ \\
\hline Observations & 12671868 & & & 4080600 & & \\
\hline
\end{tabular}

Standard errors in parentheses ${ }^{*} p<0.05,{ }^{* *} p<0.01,{ }^{* * *} p<0.001$ 
Finally, real estate ownership decreases the probability to migrate both for the working population and for the retirees. Migrating implies a more risky behavior for owners than renters, especially if the latter support high housing costs (Kallan, 2003).

Table 6: Locational characteristics and intra-zone migration

\begin{tabular}{|c|c|c|c|}
\hline & & $\begin{array}{l}\text { Working } \\
\text { population }\end{array}$ & Retirees \\
\hline Unemployment rate & UNEMPL & $\begin{array}{c}-0.5064^{* * *} \\
(0.0308)\end{array}$ & $\begin{array}{l}-0.8189 \\
(0.2976)\end{array}$ \\
\hline Median fiscal Income & MED FISC.INC & $\begin{array}{c}-0.3562^{* *} \\
(0.1076)\end{array}$ & $\begin{array}{l}-0.4713^{*} \\
(0.09477)\end{array}$ \\
\hline Gini & GINI & $\begin{array}{l}11.032 \\
(2.321)\end{array}$ & $\begin{array}{c}7.669 \\
(1.8111)\end{array}$ \\
\hline Urban density & URB & $\begin{array}{c}1.0232^{* * *} \\
(0.0043)\end{array}$ & $\begin{array}{c}1.1407^{* *} \\
(0.0509)\end{array}$ \\
\hline Collective Services & SCOL & $\begin{array}{c}-0.8343^{*} \\
(0.1174)\end{array}$ & $\begin{array}{c}-0.1108^{*} \\
(0.5629)\end{array}$ \\
\hline Immaterial Services & SIMM & $\begin{array}{l}-1.8732 \\
(0.9835)\end{array}$ & $\begin{array}{c}0.9634^{* * *} \\
(0.0873)\end{array}$ \\
\hline High Human capital activities & IINT & $\begin{array}{c}0.7922^{* * *} \\
(0.0423)\end{array}$ & $\begin{array}{l}0.0311^{*} \\
(0.0082)\end{array}$ \\
\hline Criminality rate & CRIM & $\begin{array}{c}0.3448 * * \\
(0.0866)\end{array}$ & $\begin{array}{c}0.4904^{* *} \\
(0.1966)\end{array}$ \\
\hline Sunshine & SUN & $\begin{array}{c}-0.18722^{* * *} \\
(0.0743)\end{array}$ & $\begin{array}{c}-0.3364^{* *} \\
(0.0982)\end{array}$ \\
\hline Elderly Stock & ELD STOCK & & $\begin{array}{c}0.9013^{* * *} \\
(0.0083)\end{array}$ \\
\hline Observations & & 364 & 364 \\
\hline
\end{tabular}

Standard errors in parentheses

${ }^{*} p<0.05,{ }^{* *} p<0.01,{ }^{* * *} p<0.001$

Next, we focus on intra-zone migration, that is, on the migrants who quit their county but not their zone d'emploi. Between 2003 and 2008, 1.82 million working people and 374.4 thousand retirees from a total of 12.67 million people have chosen a new location within the zone d'emploi they have been living. Table 6 delivers the results from the regression of the intra-zone migration rate (Mig_Intra reports the number of people that have moved compared to the total population of the zone) to the locational characteristics of the French zones d'emploi in order to determine which types of zone enhance stronger internal locational mobility.

Several conclusions can be drawn. First, retirees are more mobile within the zones that feature high urban density, an important tourist and cultural activity, high criminality rates and low sunshine. This is typically the case of many French urban economically attractive zones. The elderly migrants within these zones don't wish to quit the area they've been living, for various reasons such as family, social and cultural 
environment or affective ties, but still decide to move to a neighboring county in search of a better quality of life.

When comparing these results to the ones for the working population, one can see that the unemployment rate isn't significant for the retirees while it captures quite well the intra-zone mobility of the working people. The zones d'emploi with high unemployment meet low intra-zone mobility, since people either refrain from moving elsewhere because of the tension in the local labor market or they can't simply do it because they're economically fragile. This is a quite typical situation in old industrial areas, more or less affected by the economic crisis. High human capital activity zones also feature important intra-zone mobility for the working population. This is the case of large metropolitan areas, smart cities or high-tech zones. This type of activities doesn't seem to affect the retirees' movements.

Table 7 delivers the results from a probit model for inter-zone migration, combining personal attributes and locational characteristics. The first column features the probit coefficients and the second one the average marginal effects for each group, working population and retirees. The results are quite significant at $p>0.01$. Two series of conclusions can be made: the first ones concern the way individual characteristics affect the probability to migrate; the second ones show how the departure and arrival zones' locational characteristics' differentials influence this decision.

The effect of age on the probability to migrate between the zones is much stronger for the working population than for the elderly. For a working person, the probability to migrate decreases $2.3 \%$ every year, while this rate falls to $0.76 \%$ for retirees. This is consistent with previous similar findings in France (Puig, 1981; Courgeau and Meron, 1995; Gobillon, 2001; Christel, 2006). According to Christel (2006), there is an over-80-years old light, but specific, migration trend in France, usually with migrants moving to a nursing home or to an area with specific medical care (Angelini and Lafarrere, 2012). However, the late-age migration rates remain quite low.

Education positively affects both sub-groups. However the marginal effects vary substantially and are higher for the working population than for the retirees. A probable explanation for this could be that the proportion of retirees with at least a high-school diploma is very low. In this case an inferior level of educational attainment could have been more accurate, but there is no available data, other than the educational degree.

As expected, the owner/tenant position in 2008 is significant and negatively correlated with the migration probability for both types of population, workers and retirees. Marginal effects are higher for working people than for retirees because the latter may choose to combine a change in location with the change in the size or the type of dwelling (Gobillon and Wolff, 2011). This also means that for some seniors, being an owner appears as a constraint for mobility as predicted by Burkhauser et al. (1995). 
Table 7: An Empirical Probit model for elderly migration in France

\begin{tabular}{|c|c|c|c|c|}
\hline \multirow[t]{3}{*}{ Model } & \multicolumn{4}{|c|}{ Probit P(MIGZE) } \\
\hline & \multicolumn{2}{|c|}{ Active Population } & \multicolumn{2}{|c|}{ Retirees } \\
\hline & Coef & Marg.effect & Coef & Marg.effect \\
\hline \multirow[t]{2}{*}{ AGE } & $-0.110^{* * *}$ & $-0.0230^{* * *}$ & $-0.0880^{* * *}$ & $-0.0076^{* * *}$ \\
\hline & $\left(3.6310^{-4}\right)$ & $\left(7.4510^{-5}\right)$ & $\left(2.4710^{-4}\right)$ & $\left(2.4910^{-5}\right)$ \\
\hline \multirow[t]{2}{*}{$\mathrm{AGE}^{2}$} & $0.0009^{* * *}$ & $0.0002^{* * *}$ & $0.0005^{* * * *}$ & $0.00005^{* * *}$ \\
\hline & $\left(4.7510^{-6}\right)$ & $\left(9.8510^{-7}\right)$ & $\left(2.3410^{-6}\right)$ & $\left(2.1910^{-7}\right)$ \\
\hline \multirow[t]{2}{*}{ EDUC (LESS HS) } & $-0.357^{* * *}$ & $-0.0742^{* * *}$ & $-0.201^{* * *}$ & $-0.0175^{* * \mu} \mu$ \\
\hline & $\left(1.1910^{-3}\right)$ & $\left(2.4710^{-4}\right)$ & $\left(2.6110^{-3}\right)$ & $\left(2.2810^{-4}\right)$ \\
\hline \multirow[t]{2}{*}{ ALONE } & $0.143^{* * *}$ & $0.0300^{* * *}$ & $0.0851^{* * *}$ & $0.00739^{* * *}$ \\
\hline & $\left(1.3810^{-3}\right)$ & $\left(2.8710^{-4}\right)$ & $\left(2.7210^{-3}\right)$ & $\left(2.3610^{-4}\right)$ \\
\hline \multirow[t]{2}{*}{ OWNER } & $-0.263^{* * *}$ & $-0.0549^{* * *}$ & $-0.253^{* * *}$ & $-0.0220^{* * *}$ \\
\hline & $\left(1.2210^{-3}\right)$ & $\left(2.5310^{-4}\right)$ & $\left(2.90 \quad 10^{-2}\right)$ & $\left(2.2910^{-4}\right)$ \\
\hline \multirow[t]{2}{*}{ HAB2003_DIFF } & $0.380^{* * *}$ & $0.0793^{* * *}$ & $0.437^{* * *}$ & $0.0380^{* * *}$ \\
\hline & $\left(1.2010^{-3}\right)$ & $\left(2.4510^{-4}\right)$ & $\left(2.5310^{-3}\right)$ & $\left(2.2510^{-4}\right)$ \\
\hline \multicolumn{5}{|l|}{ RETURN } \\
\hline \multirow[t]{2}{*}{ DIFF_SUN } & -0.0009 & 0.0002 & $0.0209^{* * *}$ & $0.0018^{* * *}$ \\
\hline & $\left(5.0910^{-4}\right)$ & $\left(1.0610^{-4}\right)$ & $\left(5.9510^{-4}\right)$ & $\left(5.0610^{-5}\right)$ \\
\hline \multirow[t]{2}{*}{ DIFF_CRIM } & $0.0075^{* * *}$ & $0.0016^{* * *}$ & $-0.0163^{* * *}$ & $-0.0014^{* * *}$ \\
\hline & $\left(4.5310^{-4}\right)$ & $\left(9.4510^{-5}\right)$ & $\left(5.0010^{-4}\right)$ & $\left(4.2510^{-5}\right)$ \\
\hline \multirow[t]{2}{*}{ DIFF_SIMM } & $0.0187^{* * *}$ & $0.00390^{* * *}$ & $0.139^{* * *}$ & $0.0121^{* * *}$ \\
\hline & $\left(1.2110^{-3}\right)$ & $\left(2.5210^{-4}\right)$ & $\left(3.6310^{-3}\right)$ & $\left(3.1110^{-4}\right)$ \\
\hline \multirow[t]{2}{*}{ DIFF_ELD_STOC } & & & $4.126^{* * *}$ & $0.700^{* * *}$ \\
\hline & & & $\left(3.1010^{-1}\right)$ & $\left(2.2010^{-2}\right)$ \\
\hline \multirow[t]{2}{*}{ DIFF_SCOL_1999 } & $0.110^{* * *}$ & $0.0230^{* * *}$ & $0.275^{* * *}$ & $0.0239^{* * *}$ \\
\hline & $\left(6.2710^{-3}\right)$ & $\left(1.3110^{-3}\right)$ & $\left(1.5310^{-2}\right)$ & $\left(1.3310^{-3}\right)$ \\
\hline \multirow[t]{2}{*}{ DIFF_GINI } & $-5.110^{* * *}$ & $-0.648^{* * *}$ & $-6.253^{* * *}$ & $-0.5433^{* * *}$ \\
\hline & $\left(1.0610^{-1}\right)$ & $\left(2.2110^{-2}\right)$ & $(1.18$ 10-1) & $\left(1.0510^{-2}\right)$ \\
\hline \multirow[t]{2}{*}{ DIFF_MEDFISCIN } & $0.00001^{* * *}$ & $0.00002^{* * *}$ & $-0.0012^{* * *}$ & $-0.00008^{* * *}$ \\
\hline & $\left(6.3910^{-7}\right)$ & $\left(1.3310^{-7}\right)$ & $\left(1.82 \quad 10^{-6}\right)$ & $\left(1.5710^{-7}\right)$ \\
\hline \multirow[t]{2}{*}{ DIFF_IINT } & $0.419^{* * *}$ & $0.0874^{* * *}$ & $0.459^{* * *}$ & $0.0393^{* * *}$ \\
\hline & $\left(1.1610^{-2}\right)$ & $\left(2.4110^{-3}\right)$ & $\left(1.6510^{-1}\right)$ & $\left(1.4610^{-3}\right)$ \\
\hline \multirow[t]{2}{*}{ Constant } & $1.714^{* * *}$ & & & \\
\hline & $\left(6.4410^{-4}\right)$ & & & \\
\hline \multicolumn{5}{|l|}{ Lambda (Mills) } \\
\hline \multirow[t]{2}{*}{ /arthrho } & $-0.0835^{* * *}$ & & & \\
\hline & $\left(3.5710^{-3}\right)$ & & & \\
\hline \multirow[t]{2}{*}{ /Insigma } & $-3.607^{* * *}$ & & & \\
\hline & $\left(1.9910^{-4}\right)$ & & & \\
\hline \multirow[t]{2}{*}{ rho } & -0.0833 & & & \\
\hline & $\left(3.5510^{-3}\right)$ & & & \\
\hline \multirow[t]{2}{*}{ sigma } & 0.0271 & & & \\
\hline & $\left(5.3910^{-6}\right)$ & & & \\
\hline Observations & & 126711868 & & \\
\hline
\end{tabular}

Wald Prob > chi2 $=0.00$ 1636612.01, Log pseudo-likelihood: 23838911 ; Pseudo R2 : 0.1346

a. Standard errors for the marginal effects are computed using the Delta method.

b. Wald test on the null hypothesis that the estimated coefficients are zero.

c. ${ }^{\#} \mathrm{p}<0.05, \# \mathrm{p}<0.01$, \#\#\# $\mathrm{p}<0.001$ for the comparaison test between the 2 coefficients 
Finally, the HAB2003_DIFF is just a proxy that indicates whether a person's zone d'emploi in 2003 is different than his/her birthplace ( 0 if yes, 1 otherwise). This variable captures a person's mobility potential. Most migration theories claim that a migration's social cost (when leaving family, friends and a well-known social environment) is lower for people who have already moved once in their lifetime than for first-time movers. There is a higher propensity to move for the former compared to the latter. The HAB2003_DIFF is significantly positively correlated to the probability of migrating for both groups of people, workers and retirees. The comparison of the marginal effects for the two groups show, however, that the propensity to move is higher for the working people who, once they have moved out of their birthplace, seem eager to move again for a better job opportunity or a higher wage.

When it comes to the way the locational characteristics of the zones d'emploi affect the elderly migration decision, social and environmental issues seem important. Both the sunshine differential and the presence of touristic cultural amenities positively affect the elderly migration decision.

The elderly stock, that is, the proportion of elderly among the population, is strongly and positively correlated with the migration decision. The correction from the instrumental variable (the location of the "pieds noirs") allows us to control for endogeneity, confirmed by the Hausman test. This correlation corresponds to a pathdependent process, where already installed elderly attract new retirees; for the latter, this could be explained by the progressive development of local Silver Economies, which represent, in France, one of the most dynamic job-creating industries over the last ten years, with an annual average growth rate of $3 \%$.

The difference in the yearly number of hours of sunshine (DIFF_SUN) is positively correlated with the probability of migration for the elderly but is not significant for the working population. This result clearly shows the attractiveness of better-climate areas for the elderly. The results are consistent with elderly migration literature on climate amenities. The climate characteristics do not intervene within the workforce's migration movements ( $\beta$ is not significant), contrary to other locational-type amenities. The French elderly "heliotropism" is quite similar with what's happening in other highincome countries (US, Germany, United Kingdom).

The differences in criminality rate between the arrival and the departure zones inversely affect the migration decision for the elderly and for the working population. For the former, the outcome is as expected: the probability for migrating increases when the destination zone features a lower criminality rate. For the latter, it is the opposite: this can be explained by the fact that most young workers tend to migrate toward large agglomerations with better job opportunities and higher wages but also a higher criminality rate. These are the type of zones that elderly usually flee when retiring. 
Next, it appears clearly that both workers and retirees do not move towards the areas featuring strong income inequalities (DIFF_GINI $\beta$ is significantly negative). However, working migrants tend to locate to areas with higher fiscal income (DIFF_FISC INC $\beta$ is positive), while retirees prefer zones with a lower fiscal income level, also leading to lower real estate prices. These results fit quite well with the theoretical model of Graves and Knapp (1988), according to whom retirees search for a better quality of life in locations with low social disparities, less affected by criminality and featuring environmental amenities, but without being in competition - in the real estate market with the working migrants. For the working migrants, a possible explanation for these results relies in the shift of the workers' locational preferences during the 90s. In France, after the Second World War, rural households massively moved to the job-supply areas, especially the large French agglomerations, characterized by increasing productivity, positive returns to scale and higher wages but also stronger income inequalities. Congestion and an increasing pressure in the real estate market in these areas progressively led the new migrants to locate within the suburbs and the outskirts of these large agglomerations (Baccaini, 2001), characterized by a high mean income and lower income inequalities, but still facing urban criminality, compared to the rural or other small towns and medium-sized city areas.

Finally when it comes to the differentials in the specialization in services among the French zones d'emploi, all three variables (DIFF_SCOL, DIFF_SIMM and DIFF_IINTI) are significantly positively correlated with the probability to migrate. SIMM may be considered as a proxy for territorial attractiveness; it mainly features tourism services. The marginal effects are much higher for the elderly (0.0121) than for working people (0.0039), because the latter are less sensitive to environmental and cultural amenities than the former. In previous studies, Warnes (1994) and Newbold (1996) explore elderly migration in search of a large range of leisure and natural amenities (including scenic beauty, recreational opportunities and mild all-year-long climate) in lateindustrial societies.

IINTI is positively correlated with the migration probability for both populations. As expected, marginal effects are higher for working migrants (0.0874) than for the elderly (0.0393), because the presence of a large stock of high human-capital jobs usually goes along with a strong and diversified local economy, attractive to younger job-seekers and workers. Last but not least, public and private collective services differentials affect positively both working people and retirees, with quite similar marginal effects. Nevertheless, in the long run, retiring migrants may also lead in upgrades and shifts in the provision of local public services.

Finally, we choose to test whether the locational characteristics affect the migration distance. Modelling the migration distance meets a key problem in regressing the distance only for the movers and it does not observe the equation for the whole population, including people who do not migrate over this period. We use a two-stage Heckman model to deal with the sample selection bias by calculating the inverse Mills 
ratio l. We estimate the distance equation replacing the previous probit estimates from the first stage, constructing the 1 term and including it as an additional explanatory variable in the linear estimation of the distance equation. The $\beta$ parameters are estimated with the 2SLS method. Table 8 delivers the results from the Heckman model

Table 8: A Heckman model for the elderly migration distance in France

\begin{tabular}{|c|c|c|}
\hline \multirow[t]{2}{*}{ Model } & \multicolumn{2}{|c|}{ Heckman DIST } \\
\hline & $\begin{array}{c}\text { Active } \\
\text { Population }\end{array}$ & Retirees \\
\hline & Coef & Coef \\
\hline RETURN & $\begin{array}{l}15.95^{* * *} \\
(0.632)\end{array}$ & $\begin{array}{l}59.12^{* * *} \\
(1.702)\end{array}$ \\
\hline DIFF_SUN & $\begin{array}{c}1.969^{* * *} \\
(0.0935)\end{array}$ & $\begin{array}{l}4.997^{* * *} \\
(0.0944)\end{array}$ \\
\hline DIFF_CRIM & $\begin{array}{l}-0.622^{* * *} \\
(0.0919)\end{array}$ & $\begin{array}{l}-1.689^{* * *} \\
(0.0775)\end{array}$ \\
\hline DIFF_SIMM & $\begin{array}{l}7.666^{* * *} \\
(2.586)\end{array}$ & $\begin{array}{c}14.79^{* * *} \\
(0.613)\end{array}$ \\
\hline DIFF_ELD_STOC & $(27.76)$ & $\begin{array}{c}132.99^{* * *} \\
(27.76)\end{array}$ \\
\hline DIFF_SCOL_1999 & $\begin{array}{l}2.340 \text { SETEP } \\
(1.266)\end{array}$ & $\begin{array}{r}54.54^{* * *} \\
(3.045)\end{array}$ \\
\hline DIFF_GINI & $\begin{array}{l}11.66 \\
(24.91)\end{array}$ & $\begin{array}{c}-622.8^{* * *} \\
(25.73)\end{array}$ \\
\hline DIFF_MEDFISCIN & $\begin{array}{c}-0.0014^{* * *} \\
\left(1.2210^{-4}\right)\end{array}$ & $\begin{array}{l}-0.0094^{* * *} \\
\left(3.2510^{-4}\right)\end{array}$ \\
\hline DIFF_IINT & $\begin{array}{c}29.27^{* * *} \\
(2.707)\end{array}$ & $\begin{array}{c}101.2^{* * *} \\
(3.401)\end{array}$ \\
\hline Constant & $\begin{array}{c}228.08^{* * *} \\
(2.344)\end{array}$ & $\begin{array}{c}228.08^{* * *} \\
(2.344)\end{array}$ \\
\hline Lambda (Mills) & $\begin{array}{c}-18.11^{* * *} \\
(1.696)\end{array}$ & $\begin{array}{c}-18.11^{* * *} \\
(1.696)\end{array}$ \\
\hline Observations & 1613195 & \\
\hline
\end{tabular}

Wald Prob > chi2 $=0.00$ 1636612.01, Log pseudo-likelihood: 23838911 ; Pseudo R2 : 0.1346

a. Standard errors for the marginal effects are computed using the Delta method.

b. Wald test on the null hypothesis that the estimated coefficients are zero.

c. ${ }^{\#} \mathrm{p}<0.05,{ }^{\# \#} \mathrm{p}<0.01$, \#\#\# $\mathrm{p}<0.001$ for the comparaison test between the 2 coefficients

First, the homeland return variable (RETURN) is strongly correlated with the distance of migration, which means that people are eager to move far away in order to get back to their birthplace. The RETURN variable coefficient is much stronger for retirees (RETURN $\beta=59.12$ ) than for working people $(\beta=15.95)$. After retiring, for people who decide to return to their homeland, distance is not an issue, especially if one takes into account that this return-to-the-roots movement is often associated with a lower migration social cost. 
In similar studies for the US case, Warnes (1992) finds that widowhood or income collapse often generate a senior's return migration into a low-cost, often sharedwith-children housing, allowing them to preserve their standard-of-living and helping them in maintaining an active social network. Khraif (1995) establishes the fact that socially and economically "fragile" groups, that is, unmarried, low-income and non-white seniors are more likely to return to their homeland than other retirees. According to Frey et al. (2000) return migration often implies a short-distance trip, to the contrary of other elderly migrants aiming to have a better quality of life. These results are compatible with the ones we deliver for the French case, even though the community effect is weaker in France than in the US.

Second, as expected, the differences in sunshine between the French zones strongly affect the migration distance, especially for the elderly (DIFF_SUN $\beta=4.997$ vs $\beta=1.995$ for working people). Once again, this confirms previous studies according to which retirement leads to long-distance migration trips of seniors from cities to attractive rural and peripheral locations. The northern and north-eastern French zones with cold and rainy winters usually serve as departure areas, while the south Mediterranean zones with mild winters and clear skies are the destination areas.

Third, lower criminality, lower income disparities and lower mean fiscal income clearly affect the mean distance of migration for retirees. After retirement, people are likely to move far away to south or south-western France, but not to the large cities where crime rate, income disparities and real estate prices are high. They prefer, instead, to move to the rural and small-town areas that benefit from a nice climate without supporting negative externalities affecting neighboring urban zones, where most working migrants tend to congregate.

The results from the Heckman model deliver evidence that after retirement, people are willing to move far away as long as their migration corresponds either to a return to their birthplace or to a location to an area with higher quality of life standards, that is sun, security, social peace, a nice environment and, if possible, low real estate prices. This type of area corresponds quite well to the rural and semi-rural zones in south and south-western France.

\section{Conclusion - discussion}

The aim of this paper is to study elderly migration in France between 2003 and 2008. This work had to manage an important amount of data. Its primal added-value relies on the fact that it uses several original datasets: first, a unique INSEE dataset with information on individual characteristics for 12.67 million people over 18 years old, also indicating whether a person has moved or not between 2003 and 2008. In France, there is no available data on individual income which leads to collapsing individual heterogeneity mainly in human capital but also in age and family type.; second, an original spatial dataset with locational characteristics for the zones d'emploi level, which represent the most accurate geographical 
level for regional economic analysis in France. These two databases had not been explored until now, and allow us to deliver a single and robust analysis of late-life migration in France.This work builds upon a series of empirical probit and Heckman models. The results can be summarized as follow:

First, elderly migrate less than working people, which is consistent with Becker's (1964) assumption, according to which age is negatively correlated with regional migration. However, the elderly still represent $11 \%$ of the total French migrants between 2003 and 2008. These demographical flows affect the departure and the destination areas in terms of local public services, final goods demands and real estate prices.

Second, disparities in individual characteristics, mainly the human capital level, appear as an important determinant for the migration decision. Highly educated people are more likely to migrate than others, both for the elderly and for the workers.

Third, the locational characteristics of the French zones d'emploi affect the decision to move. The elderly migrate either to return to their birthplace or to move to nice-weather, attractive areas with low criminality and affordable real estate prices.

Finally, there seems to be an important spatial path-dependent process in the retirees' migration with the progressive appearance of some top elderly dominated territories, where there are new opportunities for Silver Economy growth but also for intergenerational conflicts. This may also negatively affect some departure zones in the medium and long term. The latter find themselves trapped in a circular model where the decrease in the mean local taxable income due to out-migration leads to a lower provision of collective services, which pushes more people to leave the area. In this case, contrary to Tiebout's (1956) spatial equilibrium assumption, migration generates a higher inter-zone inequality.

Future work on elderly migration in France can follow different steps: first, a similar analysis at the 36,570 counties' level could allow the tracking of short migration trips due to reasons that have not necessarily been taken into account in the present study. Second, testing the retirees' decision to migrate by taking into account their children or their family's preferences can deliver further information on the elderly migration. However, such type of data is unavailable, especially for such a large database. Third, the economic impacts of elderly migration and the perspectives for growth of localized Silver Economies is a subject that both researchers and local economic and social policy workers should consider over the next years

\section{References}

Angelini V., Laferrere A., 2012, Residential mobility of the European elderly, CESifo Economic Studies, 58(3), 544-569.

Assadian A., 1995, Fiscal determinants of migration to a fat-growing State: how the aged differ from the general population, Review of Regional Studies, 25(3), 301-315. 
Baccaini B., 2001, Les migrations en France entre 1990 et 1999, INSEE première, 758.

Becker G., 1964, Human capital, Columbia University Press.

Beckhusen A., Florax R., Poot J., Waldorf B., 2013, Attracting Global Talent and then What? Over-education among Immigrants in the US. Journal of Regional Science, 53(5), 834-854.

Bonet C., Gobillon L., Laferrère A., 2010, The effect of widowhood on housing and location choices, Journal of Housing Economics, 19, 106-120.

Börsch-Supan A., Hajivassiliou V., Kotlikoff L., Morris J., 1990, Health, children and elderly living arrangements: A multi-period-multinomial probit model with unobserved heterogeneity and auto-correlated errors, NBER Working paper W3343.

Börsch-Supan, K. Hank, H. Jürges, M. Schröder (eds.), 2008, Health, ageing and retirement in Europe (2004-2007), Starting the longitudinal dimension, Mannheim Research Institute for the Economics of Aging (MEA), University of Mannheim.

Cavailhès J., Joly D., Hilal M., Brossard T., Cardot H., Wavreski P., 2009, The price of climate: revealed preferences of French consumers, Acts of the World Bank $5^{\text {Th }}$ Urban Research Symposium.

Chesire P., Magrini S., 2006, Population growth in European cities: weather matters-but only nationally, Regional Studies, 40 (1), 23-37.

Chiuri M., Jappelli T., 2010, Do the elderly reduce housing equity? An international comparison, Journal of Population Economics, 23, 643-663.

Christel V., 2006, Trajectoires résidentielles des personnes âgées, Données Sociales, La Société, 525-529.

Clark D., Knapp T., White N., 1996, Personal and location specific characteristics and elderly interstate migration, Growth and Change, 27, 3, 327-351.

Conway K., Houtenville A., 1998, Do the elderly "vote with their feet?", Public Choice, 97:4, 663-685.

Conway K., Rork J., 2006, State 'Death' Taxes and Elderly Migration. The Chicken or the Egg? National Tax Journal, Volume LIX (1).

Courgeau D., Meron M., 1995, Mobilité résidentielle, activité et vie familiale des couples, Economie et Statistique, 290, 17-31.

Dennett A., Wilson A., 2013, A multi-level spatial interaction modelling framework for estimating inter-regional migration in Europe, Environment and Planning $A, 45,1491-1507$.

Di Pasquale D., Glaeser E., 1999, Incentives and social capital: are homeowners better citizens? Journal of Urban Economics, 45, 354-384. 
Ermisch J., Jenkins S., 1999, Retirement and housing demand by the elderly: wealth, cash flow and demographic effects, in Wise D. (eds), Economics of Aging, University of Chicago Press, 311-333.

Feinstein J., McFadden D., 1989, The dynamics of housing demand by the elderly: wealth, cash flow and demographic effects, in Wise D. (eds), Economics of Aging, University of Chicago Press, 55-91.

Findely S., 1988, The directionality and age selectivity of the health-migration relation; evidence from sequences of disability and mobility in the United-States, International Migration Review, 22:3, 4-29.

Flavin M., Nakagawa S., 2008, A model of housing in the presence of adjustment costs: a structural interpretation of habit persistence, American Economic Review, 98, 474-495.

Fokkema T., 1996, Residential moving behavior of the elderly: an explanatory analysis for the Netherlands, VU Amsterdam, Ph.D. thesis.

Frey W., Liaw K., Lin G., 2000, State magnets for different elderly migrant types in the United States, International Journal of Population Geography, 6:1, 21-44.

Gale R., Heath, C., 2000, Elderly Internal Migration in the United States Revisited, Public Finance Review, 28, 153-170

Gallaway L., 1969, Age and labor mobility patterns, Southern Economic Journal, $36,171-180$.

Glaeser E., Gottlieb J., 2009, The Wealth of Cities: Agglomeration Economies and Spatial Equilibrium in the United States, Journal of Economic Literature, 47(4), 983-1028.

Glaeser E., Tobio K., 2008, The rise of the Sunbelt, Southern Economic Journal, 74(3), 610-643.

Glaeser E., Gyourko J., Saks R., 2006, Urban Growth and Housing Supply, Journal of Economic Geography, 6(1), 71-89.

Gobillon L., 2001, Emploi, logement et mobilité résidentielle, Économie et Statistique, 349-350.

Gobillon L., Laferrere A., 2006, Les choix de logement des personnes âgées : consommation et épargne, Revue française d'économie, 20(3), 115-161.

Gobillon L., Le Blanc D., 2004, L'impact des contraintes d'emprunt sur la mobilité résidentielle et les choix de statut d'occupation des ménages: un modèle simple de demande, Annales d'Economie et de Statistique, 74, 15-46.

Gobillon L., Wolff F-C., 2011, Housing and location choices of retiring households: Evidence from France, Urban Studies, 48(2), 331-347.

Gradstein M., Kaganovich M., 2004, Aging population and education finance, Journal of public economics, 88:12, 2469-2485. 
Graves P., Knapp T., 1988, Mobility behavior of the elderly, Journal of Urban Economics, 24, 1-8.

Graves P., Knapp T., 1989, On the role of amenities in models of migration and regional development, Journal of Regional Science, 29, 71-87.

Graves P., Linneman P., 1979, Household migration: theoretical and empirical results, Journal of Urban Economics, 6, 383-404.

Hazelrigg, L. E., Hardy, M., 1995, Older Adult Migration to the Sunbelt: Assessing Income and Related Characteristics of Recent Migrants, Research on Aging, 17, 209-234.

Hogan T., Steinnes D., 1996, Arizona sunbirds and Minnesota snowbirds: two species of the elderly seasonal migrant genus, Journal of economic and social measurement, 22:2, 129-139.

Holtz-Eakin D., Lovely M., Tosun M., 2004, Generational conflict, fiscal policy and economic growth, Journal of Macroeconomics, 26:1, 1-23.

Hong G., 2015, Examining the role of amenities in migration decisions: A structural estimation approach, Papers in Regional Science, first published online: 15/01/2015, DOI:10.1111/pirs.12154.

INSEE, 2008, Annuaire statistique 2008.

INSEE, 2015, Annuaire statistique 2011.

Joly D., Brossard T., Cardot H., Cavailhes, J. Hilal, M., Wavresky P., 2010, Les types de climat en France: une construction spatiale, Cybergeo, 23155.

Kallan J., 1993, A multilevel analysis of elderly migration, Social Science Quarterly, $74: 2,403-416$.

Khraif R., 1995, The elderly return-migration in the United States: role of place attributes and individual characteristics in destination choice, Geographical Bulletin, 37:1, 29-39.

Jurjevich J., Plane D., 2009, Ties That No Longer Bind? The Patterns and Repercussions of Age-Articulated Migration, The Professional Geographer, 61, 4-20.

Ladd H., Murray S., 2001, Intergenerational conflict reconsidered: county demographic structure and the demand for public education, Economics of Education Review, 20:4, 343-357.

Liaw K., Ledent J., 1988, Joint effects of ecological and personal factors on elderly interprovincial migration in Canada, Canadian Journal of Regional Science, 11(1), 77-100.

Longino C., 2001, Geographical distribution and migration, in Binstock R., George L., 2001, Handbook of economics and aging, Academic Section, New York, 103-124.

Lundholm E., 2015, Return to where? The geography of elderly return migration in Sweden, European Urban and Regional Studies, 22(1), 
MENESR (Ministère de l'ENseignement Supérieur et de la Recherche), 2014, Système d'information OCEAN et enquête $\mathrm{n}^{\circ} 60$ sur les résultats définitifs du baccalauréat.

Meyer J., Speare, A., 1985, Distinctively elderly mobility. Types and determinants, Economic Geography, 61:1, 79-88.

Newbold, B., 1996, Determinants of Elderly Interstate Migration in the United States, 1985-1990, Research on Aging, 18, 451-476.

Newbold, B., 2008, Interprovincial migration and retirement income transfers among Canada's older population: 1996-2001, Environment and Planning A, 40(6), 15011516.

Niedomysl T., Amcoff J., 2011, Why return migrants return: survey evidence on motives for internal return migration in Sweden. Population Space and Place, 17, 656673.

Oliver C., 2008, Retirement Migration, Routledge, London.

O'Reilly K., Benson M., 2009, Lifestyle migration: escaping to the good life? in Benson M., O’Reilly K. eds, 2009, Lifestyle Migration: Expectations, aspirations and experiences, Aldershot: Ashgate, 1-13.

Perrachi F., 2002, The European community household panel: a review, Empirical economics, 27, 63-90.

Poterba J., 1998, Demographic Change, Intergenerational linkages and public education, American Economic Review, 88:2, 315-320.

Puig J-P., 1981, La migration régionale de la population active, Annales d'Economie et de Statistique, 44, 41-79.

Plane D., Rogerson P., 1991, Tracking the baby boom, the baby bust and the echo generations: how age composition regulates US migration, Professional Geographer, 43:4, 416-430.

Rappaport J., 2007, Moving to nice weather, Regional Science and Urban Economics 37(3), 375-398.

Rice T., Pepper M., 1997, Region, migration and attitudes in the United States, Social Science Quarterly, 78:1, 83-95.

Rogerson P., Burr J., Lin. G, 1997, Changes in geographic proximity between parents and their adult children, International Journal of Population Geography, 3:2, 121-136.

Rudjitis G., 1984, Geographical research and gerontology: an overview, Gerontologist, 24, 536-542.

Silverstein M., 1995, Stability and change in temporal distance between the elderly and their children, Demography, 32:1, 29-45. 
Tatsiramos K., 2006, Residential mobility and housing adjustment of older households in Europe, IZA discussion paper 2435.

US Census Bureau, 2011, United States Census 2011.

Walters W., 2002, Later-life migration in the United States: a review of recent research, Journal of Planning Literature, 17-37, 366-380.

Waltert A., Schläpfer M., 2010. Landscape amenities and local development: A review of migration, regional economic and hedonic pricing studies $\_$Ecological Economics, 70 (2), 141-152.

Warnes A., 1994, Climate and US elderly migration rates, Papers in Regional Science, 73:3, 309-329.

Wiseman R., Roseman C., 1979, A typology of elderly migration based on the decision making process, Economic Geography, 55(4), 324-337. 